\title{
УДК 639:616.982.17
}

TАРАСОВ О.А., канд. вет. наук, ст. наук. сп., e-mail: vet@ivm.kiev.ua,

БАБКІНА М.M., e-mail: pharmwork@ukr.net,

ТЕРЕЩЕНКО C.M., e-mail: vet@ivm.kiev.ua,

ЗОЦЕНКО I.A., e-mail: vet@ivm.kiev.ua,

КРИЛЕНКО С.Ю., e-mail: kr2014@ukr.net

Інститут ветеринарної медицини НААН

\section{ВИВЧЕННЯ АНТИГЕННОЇ СПОРІДНЕНОСТІ ІЗОЛЯТІВ STREPTOCOCCUS SUIS В УКРАÏHI}

В статті наведені результати дослідження антигенної специифічності та спорідненості ізолятів Streptococсиs suis та вивчення антигенних властивостей.

В результаті проведених дослідів встановлено, щзо серед досліджених штамів найбільш антигенноактивними виявились ізоляти 10, 11, 19 та 21, які мали середній коефіцієнт специфічності у відношенні до референтного штаму від 1,60 до 1,75 та високу антигенну активність у відношенні до гомологічних та гетерологічних фенотипів збудника (коефіцієнт специифічності 1,53-1,78 ). Авірулентний ізолят 16 проявив низьку активність у відноченні до вірулентних фенотипів із коефіиієнтом специфічності від 2,01 до 2,93.

Ключові слова: Streptocoсcиs suis, антигенні властивості, ізоляти, сироватки, IФА.

Вступ. Streptococcus suis типу $2 є$ важливим патогеном для свинарства майже в усіх країнах світу. Стрептококози все частіше перебігають із ознаками менінгітів, артритів, ендокардитів, септицемії, пневмонії та іноді характеризуються раптовою загибеллю свиней [1-4]. Більшість випадків припадає на вікову групу поросят від 3 до 12 тижнів, особливо небезпечна ця інфекція для тварин після відлучення (Lamont et al., 1980) [5].

На сьогодні зареєстровано 35 різних капсулярних серотипів S. suis (Perch et al., 1983; Gottschalk et al., 1989, 1991; Higgins et al., 1995) [3, 6-8].

В останні роки спостерігається значне зростання поширеності стрептококових інфекцій, а також їх роль як ускладнюючого фактору перебігу вірусних та бактерійних захворювань [9-11].

Важливість вирішення проблеми стрептококозів має соціальне значення, оскільки так звані горизонтальні генетичні обміни стрептококів призводять до формування штамів збудника із новими патогенними властивостями, які можуть бути небезпечними для людини, а на фоні метицилінрезистентності особливо небезпечними, оскільки важко піддаються антибіотикотерапії.

Враховуючи всі ці посилання, ми вважаємо, що розроблення специфічних засобів профілактики $є$ найважливішим напрямком щодо ліквідації даного захворювання.

Метою роботи було вивчення антигенної спорідненості та специфічності ізолятів S. suis.

Матеріали та методи досліджень. В роботі були використані штами та ізоляти мікроорганізму S. suis, що зберігаються та підтримуються в Інституті ветеринарної медицини (табл. 1). 
Табличя 1

Штами та ізоляти S. suis, що використовувались в дослідах

\begin{tabular}{|c|c|c|c|c|}
\hline № п/п & Назва & Серотип & Фенотип & $\begin{array}{c}\text { Вірулентність для } \\
\text { тварин }\end{array}$ \\
\hline 1 & NCTC 10234 & 2 & MRP+EF+ & вірулентний \\
\hline 2 & 10 & 2 & MRP-EF+ & вірулентний \\
\hline 3 & 21 & 2 & MRP+EF+ & високовірулентний \\
\hline 4 & 19 & 2 & MRP+EF+ & високовірулентний \\
\hline 5 & 11 & 2 & MRP+EF+ & високовірулентний \\
\hline 8 & 17 & 2 & MRP+EF+ & середньовірулентний \\
\hline 9 & 14 & 2 & MRP+EF- & середньовірулентний \\
\hline 10 & 31 & 2 & MRP+EF- & слабовірулентний \\
\hline 11 & 16 & 2 & MRP-EF- & авірулентний \\
\hline
\end{tabular}

В якості референтного використовували штам NCTC 10234.

Штами та ізоляти $S$. suis культивували у м'ясопептонному бульйоні Хоттінгера (МПБХ) з вмістом (\%): пептону - 0,5; натрію хлориду - 0,2; калію фосфорнокислого однозаміщеного - 0,3; натрію фосфорнокислого двохзаміщеного - 2; детергенту Tween-80 - 0,05; сироватки крові великої рогатої худоби, коней або овець - 8-10; глюкози - 0,4; амінного азоту $180-200$ мг \%. Поживне середовище мало $\mathrm{pH} 7,4-7,6$. Інші дослідження проводили на стандартних середовищах МПА, МПБ, середовищі Сабуро.

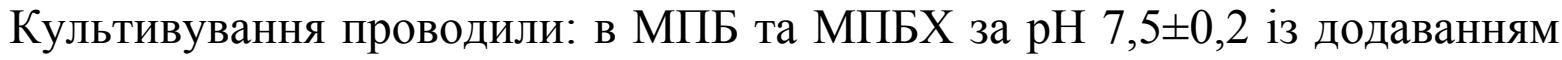
інактивованої сироватки крові ВРX в кількості 8-10\% за температури $36,7 \pm 0,3^{\circ} \mathrm{C}$ протягом 12-24 годин і в МПАХ протягом 48-72 годин.

Для вивчення антигенних властивостей досліджуваних стрептококів використовували імуноферментний аналіз (IФА) у вигляді непрямого варіанту. Реакцію проводили на 96 лункових стрипованих пластикових планшетах $\left(\right.$ Sarstedt $\left.{ }^{\circledR}\right)$.

В кожну лунку вносили по $100 \mu \mathrm{L}$ очищеного загальноклітинного антигену, в розведеннях: $5 \mu \mathrm{g} / \mathrm{mL}, 7,5 \mu \mathrm{g} / \mathrm{mL}, 10 \mu \mathrm{g} / \mathrm{mL}$ та $15 \mu \mathrm{g} / \mathrm{mL}$ в 0,05 М карбонатно-бікарбонатному буфері (pH 9,6). Інкубували 1 годину за температури $37 \pm 0,3^{\circ} \mathrm{C}$, потім тричі промивали $300 \mu \mathrm{L}$ PBS-0,05\% Tween-20 (PBST, pH 7,2). Кожну лунку блокували $100 \mu \mathrm{L}$ 5\% розчином сухого молока в PBS протягом однієї години за температури $37 \pm 0,3^{\circ} \mathrm{C}$. Потім всі плашки інкубували протягом 60 хвилин за температури $37 \pm 0,3^{\circ} \mathrm{C}$, промивали тричі PBST (pH 7,2) та вносили $100 \mu \mathrm{L}$ розведення 1:5000 анти-мишиного кон'югату у 5\% розчині сухого молока у PBST. Після інкубування протягом 60 хвилин та промивання,в кожну лунку вносили $100 \mu \mathrm{L}$ TMB субстрата та зупиняли реакцію після 10 хвилин в темному місці додаванням $100 \mu \mathrm{L}$ стоп-реактиву у кожну лунку. Урахування реакції проводили на рідері за довжиною хвилі 450 нм.

За проведення імуноферментного аналізу ми використовували негативні сироватки крові до збудника стрептококозу свиней від інтактних білих мишей та імунні (позитивні) сироватки крові від мишей, імунізованих антигеном, 
отриманим із інактивованих бактерійних культур збудника стрептококозів свиней.

Для отримання гіперімунної сироватки крові, мишей імунізували суспензією живих мікроорганізмів. Підшкірно, в ділянці спини, тваринам вводили суспензію, що містила $2,5 \times 10^{6}$ мікробних клітин 3 додаванням неповного ад’юванту Фрейнда до $20 \%$ від об'єму, в дозі $0,5 \mathrm{~cm}^{3}$. Повторну імунізацію проводили через 14 днів у тій же дозі. Через 21 добу після останнього щеплення тваринам вводили суспензію живих мікроорганізмів у кількості $5 \times 10^{6}$ КУО в дозі $1 \mathrm{~cm}^{3}$.

Сироватку отримували 3 крові, яку відбирали на 20-ий день після останнього введення антигену з серця у кількості до $5 \mathrm{~cm}^{3}$ від мурчаків та біля 1 $\mathrm{cm}^{3}$ від мишей.

Результати

експериментальних

досліджень

оброблені загальноприйнятими методами статистики (Ашмарін I. П., Воробйов А.А., 1962) 3 використанням програмного пакету «R». При цьому застосовували статистичні функції: середнє квадратичне відхилення, достовірність різниці між середніми величинами (критерій Стьюдента). Також визначали коефіцієнт специфічності в ІФА.

Результати досліджень та їх обговорення. Було проведено серію дослідів 3 вивчення антигенних властивостей ізолятів збудника стрептококозів свиней 11 ізолятів із застосуванням гомологічних та гетерологічних сироваток та відібрано 4 ізоляти $S$. suis, які проявили найвищу антигенну активність у відношенні до гомологічних та гетерологічних сироваток крові лабораторних тварин.

Серед досліджених штамів найбільш антигенноактивними виявились ізоляти 10, 11, 19 та 21, які мали середній коефіцієнт специфічності у відношенні до референтного штаму від 1,60 до 1,75 та високу антигенну активність у відношенні до гомологічних та гетерологічних фенотипів збудника (коефіцієнт специфічності 1,53 - 1,78). Авірулентний ізолят 16 показав низьку активність у відношенні до вірулентних фенотипів із коефіцієнтом специфічності від 2,01 до 2,93 (табл. 2).

Відносно низька антигенна активність по відношенню до гомологічної сироватки та висока - до гетерологічної, на нашу думку, свідчить про те, що мікроорганізми високовірулентних ізолятів несуть на своїй поверхні приблизно таку ж кількість антигенних детермінант, але вони, ймовірно, значно гірше презентовані (антигени занурені вглиб капсули, невигідне просторове розташування білкових антигенів).

Антигени високопатогенних ізолятів $S$. suis $11, \quad 19$ та 21 характеризувались вираженою антигенною активністю як по відношенню до гомологічних сироваток, так і по відношенню до сироваток, отриманих на досліджувані 17 патогенних ізолятів, які відрізнялися за ознаками патогенності. 
Табличя 2

Специфічність гіперімунних сироваток у відношенні до антигенів штамів та ізолятів S. Suis, $\mathrm{M} \pm \mathbf{M}, \mathrm{n}=3$

\begin{tabular}{|c|c|c|c|c|c|c|c|c|c|}
\hline \multirow[b]{2}{*}{$\begin{array}{l}\text { Гіперімунні } \\
\text { сироватки }\end{array}$} & \multicolumn{9}{|c|}{ Антигени } \\
\hline & $\begin{array}{l}\text { NCTC } \\
10234\end{array}$ & 10 & 11 & 14 & 16 & 17 & 19 & 21 & 31 \\
\hline $\begin{array}{l}\text { NCTC } \\
10234\end{array}$ & $\begin{array}{c}1,14 \pm \\
0,12\end{array}$ & $\begin{array}{c}0,68 \pm \\
0,07\end{array}$ & $\begin{array}{c}0,65 \pm \\
0,06\end{array}$ & $\begin{array}{c}0,58 \pm \\
0,07\end{array}$ & $\begin{array}{c}0,54 \pm \\
0,11\end{array}$ & $\begin{array}{c}0,59 \pm \\
0,08\end{array}$ & $\begin{array}{c}0,67 \pm \\
0,07\end{array}$ & $\begin{array}{c}0,71 \pm \\
0,05\end{array}$ & $\begin{array}{c}0,69 \pm \\
0,08\end{array}$ \\
\hline $\mathrm{K}$ & - & $1,67^{*}$ & $1,75 *$ & 1,96 & 2,11 & 1,93 & $1,70 *$ & $1,60 *$ & $1,72 *$ \\
\hline 10 & $\begin{array}{l}0,65 \pm \\
0,07\end{array}$ & $\begin{array}{l}1,32 \pm \\
0,21\end{array}$ & $\begin{array}{l}0,65 \pm \\
0,12\end{array}$ & $\begin{array}{l}0,58 \pm \\
0,07\end{array}$ & $\begin{array}{l}0,61 \pm \\
0,11\end{array}$ & $\begin{array}{l}0,59 \pm \\
0,12\end{array}$ & $\begin{array}{l}0,65 \pm \\
0,09\end{array}$ & $\begin{array}{l}0,69 \pm \\
0,05\end{array}$ & $\begin{array}{l}0,55 \pm \\
0,17\end{array}$ \\
\hline $\mathrm{K}$ & 2,03 & - & 2,03 & 2,27 & 2,16 & 2,23 & 2,03 & 1,91 & 2,40 \\
\hline 11 & $\begin{array}{l}0,78 \pm \\
0,06\end{array}$ & $\begin{array}{l}0,79 \pm \\
0,11\end{array}$ & $\begin{array}{l}1,28 \pm \\
0,05\end{array}$ & $\begin{array}{l}0,70 \pm \\
0,11\end{array}$ & $\begin{array}{l}0,64 \pm \\
0,06\end{array}$ & $\begin{array}{l}0,65 \pm \\
0,12\end{array}$ & $\begin{array}{l}0,76 \pm \\
0,05\end{array}$ & $\begin{array}{l}0,82 \pm \\
0,10\end{array}$ & $\begin{array}{l}0,74 \pm \\
0,04\end{array}$ \\
\hline K & $1,64 *$ & $1,62 *$ & - & 1,82 & 2,01 & 1,96 & $1,68 *$ & $1,56^{*}$ & $1,72 *$ \\
\hline 14 & $\begin{array}{l}0,50 \pm \\
0,06\end{array}$ & $\begin{array}{l}0,63 \pm \\
0,15 \\
\end{array}$ & $\begin{array}{l}0,78 \pm \\
0,09 \\
\end{array}$ & $\begin{array}{l}1,41 \pm \\
0,12 \\
\end{array}$ & $\begin{array}{l}0,55 \pm \\
0,12\end{array}$ & $\begin{array}{l}0,49 \pm \\
0,06\end{array}$ & $\begin{array}{l}0,75 \pm \\
0,10 \\
\end{array}$ & $\begin{array}{l}0,79 \pm \\
0,07\end{array}$ & $\begin{array}{l}0,56 \pm \\
0,14\end{array}$ \\
\hline $\mathrm{K}$ & 2,82 & 2,23 & $1,80 *$ & - & 2,56 & 2,87 & $1,88 *$ & $1,78 *$ & 2,51 \\
\hline 16 & $\begin{array}{l}0,45 \pm \\
0,07\end{array}$ & $\begin{array}{l}0,41 \pm \\
0,11\end{array}$ & $\begin{array}{l}0,69 \pm \\
0,05\end{array}$ & $\begin{array}{l}0,45 \pm \\
0,14\end{array}$ & $\begin{array}{l}1,24 \pm \\
0,10\end{array}$ & $\begin{array}{l}0,55 \pm \\
0,08\end{array}$ & $\begin{array}{l}0,67 \pm \\
0,08\end{array}$ & $\begin{array}{l}0,65 \pm \\
0,12\end{array}$ & $\begin{array}{l}0,48 \pm \\
0,05\end{array}$ \\
\hline $\mathrm{K}$ & 2,75 & 3,02 & $1,79 *$ & 2,75 & - & 2,25 & $1,85^{*}$ & $1,86^{*}$ & 2,58 \\
\hline 17 & $\begin{array}{l}0,55 \pm \\
0,08\end{array}$ & $\begin{array}{l}0,47 \pm \\
0,05\end{array}$ & $\begin{array}{l}0,56 \pm \\
0,04\end{array}$ & $\begin{array}{l}0,49 \pm \\
0,14\end{array}$ & $\begin{array}{l}0,52 \pm \\
0,09\end{array}$ & $\begin{array}{l}1,35 \pm \\
0,05\end{array}$ & $\begin{array}{l}0,57 \pm \\
0,03\end{array}$ & $\begin{array}{l}0,59 \pm \\
0,11\end{array}$ & $\begin{array}{l}0,61 \pm \\
0,15\end{array}$ \\
\hline $\mathrm{K}$ & 2,45 & 2,87 & 2,41 & 2,75 & 2,59 & - & 2,36 & 2,28 & 2,21 \\
\hline 19 & $\begin{array}{l}0,75 \pm \\
0,12\end{array}$ & $\begin{array}{l}0,69 \pm \\
0,08\end{array}$ & $\begin{array}{l}0,77 \pm \\
0,05\end{array}$ & $\begin{array}{l}0,69 \pm \\
0,09\end{array}$ & $\begin{array}{l}0,49 \pm \\
0,05\end{array}$ & $\begin{array}{l}0,74 \pm \\
0,07\end{array}$ & $\begin{array}{l}1,21 \pm \\
0,10\end{array}$ & $\begin{array}{l}0,79 \pm \\
0,10\end{array}$ & $\begin{array}{l}0,68 \pm \\
0,07\end{array}$ \\
\hline $\mathrm{K}$ & $1,61 *$ & $1,75 *$ & $1,57 *$ & $1,75^{*}$ & 2,46 & $1,63 *$ & - & $1,53 *$ & $1,77 *$ \\
\hline 21 & $\begin{array}{l}0,85 \pm \\
0,12 \\
\end{array}$ & $\begin{array}{l}0,75 \pm \\
0,05\end{array}$ & $\begin{array}{l}0,81 \pm \\
0,05\end{array}$ & $\begin{array}{l}0,72 \pm \\
0,06\end{array}$ & $\begin{array}{c}0,51 \pm \\
0,10\end{array}$ & $\begin{array}{l}0,65 \pm \\
0,08\end{array}$ & $\begin{array}{l}0,84 \pm \\
0,10\end{array}$ & $\begin{array}{l}1,16 \pm \\
0,15\end{array}$ & $\begin{array}{l}0,75 \pm \\
0,05\end{array}$ \\
\hline $\mathrm{K}$ & $1,36^{*}$ & $1,54 *$ & $1,43^{*}$ & $1,61 *$ & 2,27 & $1,78 *$ & $1,38 *$ & - & $1,54 *$ \\
\hline 31 & $\begin{array}{l}0,45 \pm \\
0,03\end{array}$ & $\begin{array}{l}0,48 \pm \\
0,15 \\
\end{array}$ & $\begin{array}{l}0,71 \pm \\
0,05 \\
\end{array}$ & $\begin{array}{l}0,45 \pm \\
0,06\end{array}$ & $\begin{array}{l}0,43 \pm \\
0,07\end{array}$ & $\begin{array}{l}0,49 \pm \\
0,09\end{array}$ & $\begin{array}{l}0,69 \pm \\
0,11 \\
\end{array}$ & $\begin{array}{l}0,67 \pm \\
0,07\end{array}$ & $\begin{array}{l}1,26 \pm \\
0,21 \\
\end{array}$ \\
\hline $\mathrm{K}$ & 2,8 & 2,65 & $1,77 *$ & 2,80 & 2,93 & 2,57 & $1,82 *$ & $1,88^{*}$ & - \\
\hline
\end{tabular}

Примітки: * - $\mathrm{P}<0,05, \mathrm{~K}$ - коефіцієнт специфічності.

Висока антигенна активність (спорідненність) 3 гомологічними та гетерологічними специфічними сироватками є однією з ознак, за якими ми підбирали штами-кандидати для створення вакцини проти стрептококозів свиней.

\section{Висновки та перспективи подальших досліджень:}

Виходячи $з$ представлених даних встановлено, що сироватки, отримані проти відповідних антигенів S. suis, володіють специфічністю та можуть бути використані для типізації збудника стрептококозу свиней.

Серед досліджених штамів найбільш антигенноактивними виявились ізоляти 10, 11, 19 та 21, які мали середній коефіцієнт специфічності у відношенні до референтного штаму від 1,60 до 1,75 та високу антигенну активність у відношенні до гомологічних та гетерологічних фенотипів збудника (коефіцієнт специфічності 1,53-1,78 ). Авірулентний ізолят 16 показав 
низьку активність у відношенні до вірулентних фенотипів із коефіцієнтом специфічності від 2,01 до 2,93.

Подальші дослідження антигенних властивостей S. suis будуть направлені на виготовлення експериментальних зразків вакцини проти стрептококозу свиней.

\section{СПИСОК ЛІТЕРАТУРИ}

1. Further studies on the subclinical carrier state of Streptococcus suis type 2 in pigs / F.A. Clifton-Hadley [et al] // Vet Rec. - 1984. - № 114. - P. 513-518.

2. Characteristics of different Streptoccocus suis ecovars and description of a simplified identification method /L.A. Devriese [et al]// Veterinary Microbiol. - 1991. - № 26. - P. 141-150.

3. Higgins R. An update on Streptococcus suis identification / R. Higgins, M. Gottschalk // J. Vet. Diagn. Invest. - 1990. - № 2, - P. 249-252.

4. Streptococcus suis infection in swine: a retrospective study of 256 cases. Part II. Clinical signs, gross and microscopic lesions, and coexisting microorganisms / R.Y. Reams, [et al] // J. Vet. Diagn. Invest. - 1994 - № 6. - P. 326-334.

5. Lamont M.H. Streptococcal meningitis in pigs: Results of a five-year survey / M.H. Lamont, P.T. Edwards, R.S. Windsor // Vet. Rec. - 1980. - № 107. - P. 467-469.

6. Prevalence of various phenotypes of Streptococcus suis isolated from swine in the U.S.A. based on the presence of muraminidase-released protein and extracellular factor / L. Galina [et al] // Can. J. Vet. Res. - 1996. - № 60. P. 72-74.

7. Characterization of six new capsular types (23 through 28) of Streptococcus suis I M. Gottschalk [et al] // J. Clin. Microbiol. - 1991. - № 29, - P. 2590-2594.

8. Mwaniki C.G. The prevalence of Streptococcus suis type 2 in Western Australian piggeries / C.G. Mwaniki [et al] // Australian Vet. J. - 1994. - № 71. - P. 385-386.

9. Salasia S.I. Distribution of serotype, virulence markers and further characteristics of Streptococcus suis isolates from pigs / S.I. Salasia, C. Lammler // Zentralbl. Veterinarmed. 1995. - № 42. - P. 78-83.

10. Comparative studies on the pathogenicity of different Streptococcus suis type 1 strains/ N.Stockhofe-Zurwieden [et al] // Proceedings of the 14th IPVS Congress, Bologna, 1996. - P. 299.

11. Repeats in an extracellular protein of weakly pathogenic strains of Streptococcus suis are absent in pathogenic strains / H.E. Smith [et al]// Infect. Immun. - 1993. - № 61, - P. 3318-3326.

ИЗУЧЕНИЕ АНТИГЕННОГО РОДСТВА ИЗОЛЯТОВ STREPTOCOCCUS SUIS В УКРАИНЕ / Тарасов О.А, Бабкина М.М., Терещенко С.М., Зоценко I.А., Криленко С.Ю.

В статье приведень результаты исследования родства изолятов Streptococcus suis $u$ изучения их антигенных свойств.

В результате проведенных опытов установлено, что среди исследованных штаммов наиболее антигенноактивными были изоляты 10, 11, 19 и 21, которые имели средний коэффиџиент специфичности в отношении референтного штамма от 1,60 до 1,75 u высокую антигенную активность в отношении гомологичных и гетерологичных фенотипов возбудителя (коэффищиент специфичности 1,53-1,78). Авирулентный изолят 16 проявил низкую активность в отночении вирулентных фенотипов $c$ коэффициентом специфичности от 2,01 до 2,93.

Ключевые слова: Streptococcus suis, антигенные свойства, изоляты, сыворотки, ИФА. 
INVESTIGATION OF ANTIGENIC AFFINITY OF STREPTOCOCCUS SUIS ISOLATES IN UKRAINE / Tarasov A.A., Babkina M.M., Tereshchenko S.M., Zotcenko I.A., Krilenko S.U.

Introduction. Streptococcus suis type 2 is an important pathogen for pig industry in many countries. Today are known more than 35 different capsular serotypes of S. suis. In the last years registered the significant growth of streptococcal infections prevalence. Considering of these, the problem of prevention and treatment of streptococcosis is serious and important for pig industry susteinability. .

The goal of the work was to investigate the antigenic affinity of Streptococcus suis isolates.

Materials and methods. It was used 11 isolates of Streptococcus suis, negative and positive serums of blood. For investigations of antigenic properties it was used the inderect ELISA method with in-house prepared antigens. For isolation and characterization of strains and isolates, it was used standard bacteriological approaches and culture methods. Detection of the capsule was performed by Neifiield method.

Results of research and discussion. As a result of the experiments, it was found that among the strains studied the most antigenically active were isolates 10, 11, 19 and 21, which had an average specificity coefficient for the reference strain from 1.60 to 1.75 and high antigenic activity for homologous and heterologous phenotypes of the pathogen (A specificity factor of 1.53 - 1.78). Avirulent isolate 16 exhibited low activity against virulent phenotypes with a specificity coefficient of 2.01 to 2.93 .

Conclusions and prospects for further research:

1. Based on the data presented, it has been established that specific sera obtained against the corresponding S. Suis antigens have specificity and can be used for typing the causative agent of streptococcosis in pigs.

2. Among the strains studied, isolates 10,11,19 and 21 proved to be the most antigenically active, which should have an average specificity coefficient toward the reference strain from 1.60 to 1.75 and high antigenic activity against homologous and heterologous phenotypes of the pathogen (specificity factor 1, 53-1.78). Avirulent isolate 16 showed a low activity against virulent phenotypes with a specificity coefficient of 2.01 to 2.93 .

Therefore, further research antigenic properties of $S$. suis is an important direction of improving immunogenic potency of vaccines.

Keywords: Streptococcus suis, antigenic properties, isolates, serum, ELISA.

\section{REFERENCES}

1. Clifton-Hadley, F.A., Alexander, T.J.L., Upton, I. \& Duffus, W.P.H. (1984). Further studies on the subclinical carrier state of Streptococcus suis type 2 in pigs. Vet Rec., 114, 513-518.

2. Devriese, L.A., Ceyssens, K., Hommez, J., Kilpper-Bälz, R. \& Schleifer, K.H. (1991). Characteristics of different Streptoccocus suis ecovars and description of a simplified identification method. Veterinary Microbiol., 26, 141-150.

3. Higgins, R. \& Gottschalk, M. (1990). An update on Streptococcus suis identification. J. Vet. Diagn. Invest., 2, 249-252.

4. Reams, R.Y., Glickman, L.T., Harrington, D.D., Thacker, H.L. \& Bowersock, T.L. (1994). Streptococcus suis infection in swine: a retrospective study of 256 cases. Part II. Clinical signs, gross and microscopic lesions, and coexisting microorganisms. J. Vet. Diagn. Invest., 6, 326334.

5. Lamont, M.H., Edwards, P.T. \& Windsor, R.S. (1980). Streptococcal meningitis in pigs: Results of a five-year survey. Vet. Rec., 107, 467-469.

6. Galina, L., Vecht, U., Wisselink, H.J. \& Pijoan, C. (1996). Prevalence of various phenotypes of Streptococcus suis isolated from swine in the U.S.A. based on the presence of muraminidase-released protein and extracellular factor. Can. J. Vet. Res., 60, 72-74 
7. Gottschalk, M., Higgins, R., Jacques, M., Beaudoin, M. \& Henrichson, J. (1991). Characterization of six new capsular types (23 through 28) of Streptococcus suis. J. Clin. Microbiol., 29, 2590-2594.

8. Mwaniki, C.G., Robertson, I.D. \& Hampson, D.J. (1994). The prevalence of Streptococcus suis type 2 in Western Australian. Australian Vet. J., 71, 385-386.

9. Salasia, S.I. \& Lammler, C. (1995). Distribution of serotype, virulence markers and further characteristics of Streptococcus suis isolates from pigs. Zentralbl. Veterinarmed., 42, 78-83.

10. Stockhofe-Zurwieden, N., Vecht, U., Wisselink, H.J., Van Lieshout, H., \& Smith, H.E. (1996). Comparative studies on the pathogenicity of different Streptococcus suis type 1 strains. Proceedings of the 14th IPVS Congress. (p. 299). Bologna.

11. Smith, H.E., Reek, F.H., Vecht, U., Gielkens, A.L.J., \& Smits, M.A. (1993). Repeats in an extracellular protein of weakly pathogenic strains of Streptococcus suis are absent in pathogenic strains. Infect. Immun., 61, 3318-3326.

\section{УДК 636.09:[616.98+579.834.115]:636.1}

УХОВСБкИй В.В., д-р вет. наук, e-mail: uhovskiy@ ukr.net, Інститут ветеринарної медицини НААН

АЛЕКСЕСВА Г.Б., канд. вет. наук, e-mail: serolog@i.ua, ВОЛИНЕЦЬ В.О. ${ }^{*}$, e-mail: victoriya-volinets@ ukr.net, Державний науково-дослідний інститут лабораторної діагностики та ветеринарно-санітарної експертизи

БЕЗИМЕННИЙ М.В., e-mail: nomax@ukr.net

Інститут ветеринарної медицини НАAН

\section{КАРТОГРАФІЧНИЙ АНАЛІЗ ЦИРКУЛЯЦІї ЗБУДНИКІВ ЛЕПТОСПІРОЗУ КОНЕЙ В УКРАЇНІ}

Наведено картографічний аналіз циркуляиіі основних діагностичних серогруп лептоспір серед поголів'я коней і статистична оцінка ензоотичних територій лептоспірозу иього виду тварин у розрізі областей України. Встановлено, щзо спалахи лептоспірозу коней мають визначену екорегіональну приуроченість. Проведене картографування дозволяє здійснювати оцінку територій та визначати зони ризику зараження коней лептоспірами восьми основних діагностичних серогруп.

Ключові слова: лептоспіра, лептоспіроз, коні, реакція мікроаглютинації, картографування.

Вступ. На лептоспіроз хворіють майже всі свійські та дикі тварини: велика рогата худоба, свині, собаки, коні, єноти, миші i т.д. У коней лептоспіроз проявляється ураженням очей, сліпотою, абортами, що веде до передчасного вибракування тварин і наносить значні економічні збитки [1-4].

Лептоспіроз коней $є$ значно розповсюдженим в усьому світі, багато вчених досліджували етіологію цього захворювання. Американські вчені повідомляють, що в етіологічній структурі лептоспірозу коней у США, за даними серологічних досліджень, домінуюче значення мають серовари 